\title{
7 Europe and the 'Islamic Threat': Putting the Spectre into Perspective
}

JEREMY SALT

Samuel Huntington has argued, in a frequently cited article written for Foreign Affairs, ${ }^{1}$ that the next stage of world history will be characterised by the clash between civilisations. 'Islamic' and 'western' civilisation are two of the eight civilisations he describes. Huntington's article attracted such attention because it appeared at a time when matters relating to culture, ethnicity and identity were moving to the top of the agenda in the United States and Europe. Of all of these questions, none seemed to be more pertinent than those relating to Islam, whether in the context of European immigration or state-to-state relations, and the implications for the outside world of political change within Muslim societies. The Huntington view, that Islamic and Western civilisations are in a state of actual or incipient conflict, only fed fears that were already gathering force. The revival of religious faith taking place across the Islamic world has created a mood of apprehension not dissimilar to European fears of Pan Islam in the late 19th century or to western fears of communism in the 1950s. These concerns are summed up in remarks made by the former Secretary-General of NATO, Willy Claes, in an interview with the Süddeutsche Zeitung: 'Fundamentalism is at least as dangerous as communism was. Please do not underestimate this risk. It is our duty to organise, especially with those countries facing this kind of difficulty, a dialogue.' 2

Such views raise more questions than they answer. First, Islam cannot be reduced to a uniform religious, cultural and historical framework of ideas. It does not lend itself to simple definitions. Its history is remarkably diverse, centring on a core of beliefs common to all Muslims but otherwise subject to infinite interpretation. Islamic societies are characterised as much-if not more so-by their differences as their similarities. There is no single Islam, speaking for all Muslims in the same voice at all times, but an innumerable variety of shifting interpretations, and when Islam is presented as a threat to the West, the first task is to find out whose Islam. Mr Claes, in his statement, has provided the answer to that. It is the Islam of the fundamentalists. But not even among scholars outside Muslim societies is there agreement on what 


\section{Europe: Rethinking the Boundaries}

constitutes fundamentalism. The most regressive and repressive Islamic state in the world, Saudi Arabia, is never spoken of in the same breath as the fundamentalists of Iran, Sudan and Algeria, or the anti-state Islamic movements in other countries. What, in fact, Mr Claes and others who employ the rhetoric of the Islamic mean by fundamentalist is those movements or states that threaten the interests of the West. Governments can be as repressive as they like, but as long as they do not interfere with the grand plans and strategies of the West, which in the late twentieth century means the United States, they will never be described as fundamentalist. Thus, in the sense in which $\mathrm{Mr}$ Claes uses the word, fundamentalism is a convenient label used to invalidate and discredit movements and governments which 'the West' does not like. In the devil's dictionary used by western strategists and NATO commanders there is a close parallel not just between Islamic fundamentalism and communism but between fundamentalism and the rhetoric deployed against 'radical' Arab nationalism forty years ago. Not by coincidence, many of the objectives of the 'Islamic fundamentalists' and the 'radical nationalists' are the same, and it is the determination of the Iranian government, to take one example, to adhere to an independent domestic and regional policy that lies behind its continuing vilification in the United States. The constant use of 'the West' as some kind of polar opposite to 'Islam' should also remind us of the dramatic changes which have taken place between Europe and the United States. 'The West' no longer exists in the way it was understood forty years ago, with the differences between Europe and the United States only growing since the collapse of the USSR and the impact of globalisation on national economies. Geographically, historically and diplomatically, the Europeans approach their dealings with the Muslims closest to them-Arabs and Turks-from an entirely different perspective, and in their dealings with the governments of the Middle East they are following their own interests. They have ignored the attempt of the United States to block all commercial dealings with Iran and have shown elsewhere that they have no intention of simply following the American lead. Freed from the psychology of the Cold War, they are likely to play an even more independent role in the future.

The ability to get away with generalised statements about 'fundamentalism' is greatly enhanced by public ignorance and the willingness to believe the worst of Arabs or Muslims. Although there are honourable exceptions of both newspapers (Le Monde for example) and individual correspondents (David Hirst of The Guardian and Robert Fisk of The Independent), there is a long pattern of misrepresentation, misreporting and sensationalism in the print media on both sides of the Atlantic. The explanation for this lies in the relationships between governments and media proprietors and the way their biases percolate downwards through the editorial rooms, so that reporters 
and leader writers know instinctively how far they can go without needing to be told. The result is that readers are often given the worst and most sensational aspects of 'Islamic revivalism' and nothing else-terrorist attacks in Egypt and the fatwa against Salman Rushdie, but almost nothing of the debates taking place in all Muslim societies about contemporary problems, and nothing of the fact that the 'Islamic terrorism' which horrifies western readers is equally horrifying to the vast majority of Muslims.

The prime concern of Muslim activists everywhere is reforming the societies in which they live. By and large they fall within the mainstream and work within the law. There are conservatives and progressives among them, and moderates and extremists. They are concerned with questions of democracy and all the day-to-day issues that would preoccupy social or political movements in any country. In Algeria, Egypt and Turkey, they have demonstrated their willingness to work for change through the ballot box, and if there is any threat to democracy in these countries it has not come from the 'fundamentalists': in Algeria and Turkey it is the military that has frustrated the outcome of elections fought fairly and squarely, while in Egypt it is not just the Islamists who believe that the elections are a charade. Neither is there anything unique about such movements appearing in the late twentiethth century. Islamic revivalism is not an aberration but part of a cyclical phenomenon: there has always been an individual or a movement to challenge the assumptions of the state or to defend the umma (the community of all Muslims) when it is threatened by outside forces. It should therefore surprise no-one that the conditions of the late twentieth century - the lack of basic freedoms and rights in almost every country of the Middle East, and severe economic imbalances, but even worse the wasted potential of resources-should have called forth movements demanding change.

Thus, the first concern of Muslim movements is conditions within their own societies. They do not like the disruptive effect of 'the West' on their politics, cultures and economies; but it would be a mistake to draw the conclusion that this arises from a general Islamic hostility to 'the West' or non-Muslims. Jews and Christians have their place in the Qu'ran as ahl al kitab (people of the book) and their place in Muslim societies as the dhimmi (protected groups). Their prophets and their books are venerated by Muslims. In their dealings with the outside world the attitude of Muslims has been seriously misrepresented. Although Islam is a missionary religion, aggressive warfare is condemned and forced conversion forbidden. Clear rules are laid down for the conduct of war and the restitution of peace, and the declaration of jihad is essentially no different from the declaration of war that any state might make, except that it is declared in the name of Islam and thus in the interests of Muslims everywhere rather than in the name of a particular state. Jihad itself does not 
mean 'holy war' but merely struggle, and basically the struggle of each individual to lead a better Muslim life: yet only its most sensational meaning is known in the West.

The whole history of Islam is a struggle for meaning. The basis of law is interpretation and of community life consensus. Not since the time of the prophet or since the last of the Shi $i$ imams has a single individual been able to stand as the symbol of unchallengeable authority. The real significance of Ayatullah Khumayni was overlooked. The fatwa issued against Salman Rushdie was merely an opinion which could have been delivered on any matter involving Muslims. It was perfectly within the right of other scholars to present a different view and indeed - outside Iran - many did. Khumayni's fatwa against Rushdie had such force because he was Khumayni, not merely a religious authority but a political figure of charismatic mass appeal who was seen to have delivered Iran from its oppressors. In Iran there were religious figures of greater scholarly standing than Khumayni, and if they did not challenge his view it was not necessarily because they agreed with his interpretation but because it was scarcely wise or expedient to do so. In the case of the elderly Ayatullah ShariatMadari, who was stripped of his rank in the most humiliating way, Khumayni demonstrated how harshly he could deal with perceived rivals and enemies.

Since Khumayni's death, the Jacobin harshness of the Islamic republic has noticeably softened, with the overwhelming victory of the moderate Ayatullah Khatami to succeed Hashemi Rafsanjani as president the clearest possible indication that the Iranians want this trend to continue. In Iran as elsewhere, the struggle between the progressives and the conservatives in the legislative and executive branches of government is mirrored in the debates taking place over what is entailed in the properly fulfilled Muslim life. To some this cannot be achieved without the establishment of sharia's law; but many who are proud to call themselves Muslim-even in the most secular of Muslim societies - regard religion in the contemporary age as a matter for private belief. The battle lines move back and forth, but we need to be reminded that this debate has been taking place ever since the death of the Prophet Muhammad.

The rise of the Islamic movements in the Middle East and North Africa is clearly linked to the economic and political shortcomings of the secularised governments which have held power throughout the region since 1945 . Now there is globalisation to contend with. At times of crisis, it is natural for people to cluster defensively around what they know best, and thus the Islamic resurgence can be described as a nativist reaction to a sequence of disillusioning political, ideological and economic failures stretching over a long period of time. Muslim activists are not alone in their disillusionment. But with the apparent exhaustion of secular nationalism, Islam is making the ideological running. In all countries unredressed social grievances have greatly accelerated 
the growth of Muslim movements. If Egypt has been in a state of incipient crisis for the last twenty years, with the government struggling to contain the threat posed not just by violent Muslim groups but also by those working successfully and perhaps more dangerously within the law, it is for reasons to do with severe economic inequities, corruption and manipulation of the political system. The Muslim movements there are working to change a system (of values as well as government) which has become dysfunctional. In Saudi Arabia, the focal point of discontent is a repressive political structure. The dissidents are not underground Marxists but religious scholars who argue that kingship is anathema to Islam, and who are being jailed or are having to flee the country for urging the Saudis to democratise the system in line with the Islamic principles of consensus (ijma) and consultation (shura).

In Algeria the people are still living with long-term consequences of colonialism. The French government has continued to support the military regime which short-circuited the democratic process in 1991 so that the Islamic Salvation Front could not come to power. French support for the military has had the result of turning France into a secondary arena of conflict, and has fuelled fears that 'collapse' in Algeria 'will result in the onslaught on southern Europe's shores of a new generation of boat people fleeing a vengeful fundamentalist regime ${ }^{3}$, creating a problem not just for France but also for Europe. Developments in Algeria, along with the extension of the conflict to France through aircraft hijacking and assassinations, have - at a time of general European concern over immigration and the assimilation of migrant communities — created additional problems for North Africans already living in France.

The Algerian situation is especially complicated because no Middle Eastern or North African territory was invaded more comprehensively by a European power. Invasion was followed by colonisation and French penetration of the Algerian consciousness. The paradox of 'the land of a million martyrs' is that much of the revolutionary generation which finally came to power in 1962 was thoroughly imbued with French culture, 'speaking almost exclusively in French and demanding not the world of the Qu'ran, the Sunna, or of the local holy man but the world envisioned by European thinkers-Voltaire, Rousseau, Auguste Comte. At first assimilationists, and later liberal nationalists, these men were overwhelmingly secular in outlook and they adopted to varying degrees the life-styles of Europe and hoped to rebuild Algeria in accordance with liberal models flowing from the Enlightenment and from the experiences of nineteenth-century Europe'. 4

Even the working class leftist movement derived its inspiration from France, and only the Association of Algerian Muslim Ulama framed an anti-colonialist message that was unequivocally nativist: 'Islam is my religion, Arabic is my language and Algeria is my fatherland'. Yet it was the French-speaking elites 
who succeeded to power and have held it ever since. Language has become the supreme cultural signifier of power. As Larbi Sadiki has written 'French is central to the whole struggle for power in Algeria'. 5 This conflict between the Francophones and Arabisants has its roots in the colonial period. Here, according to Sadiki, we have 'the spiritual foundation that inspires modernday Algeria's Islamists and feeds their visceral hatred of France and the upper class of Francophone traditional power holders who symbolise foreign hegemony'. 6 Another observer writes:

.... in the eyes of the Islamic underground now fighting to destroy the Government in Algiers the struggle for religious and cultural emancipation has never been concluded. With the departure of French soldiers, Algeria found independence of a radical Third World stamp. Yet the vestiges of French identity lingeredin language, literature, newspapers, consumer products, the way the Government worked and the way intellectuals reasoned. To Islamists these represented proof that the original liberation struggle was incomplete. A pamphlet from one of the multiplicity of Islamic underground groups in 1994 described the Algiers French press-not the dailies from Paris, let it be noted, but newspapers written and edited in French by Algerians for Algerians-as 'abominations before the eyes of God. ${ }^{7}$

Accordingly the struggle of the Islamists was not just against a stale and inefficent government but against the domination of the Francophones. The reassertion of an Algerian Arab-Islamic identity carried the Islamic Salvation Front to the point of electoral victory, the short-circuiting of which has plunged Algeria into one of the darkest periods of its history. The suppression of what was regarded as a moderate Islamic movement, coming to power democratically, has had terrible consequences-initially the murder of foreigners and Algerians who stood as symbols of westernisation, and now the wholesale slaughter of the Algerian people themselves, without anyone knowing who is really responsible.

The Algerian example has been held up as a warning of what can happen when the democratic path to government is closed off to the Islamists. The socio-economic grievances stimulating the rise of the Islamic revivalism in Algeria can also be seen very clearly in Turkey, another country very much on the European mind. The deregulation of the economy by the civilian government elected in 1983, the first since the military intervened in 1980, has had serious social consequences. Inflation, the plunging value of the lira, and subsistence level salaries for the bulk of the Turkish workforce have combined to drive down living standards for most of the country's sixty million people. Demographics are also responsible. The millions of 'in migrants' from the east have helped to more than double the population of Turkey's 
biggest cities (particularly Ankara and Istanbul) in less than a decade. These newly urbanised Turks are not only at the bottom of the socio-economic pile but bring with them the traditional culture of the Anatolian village or town, in which religion is a central value. The nexus between economic inequities, demographics and traditional values helps us to understand the striking success of the Refah (Prosperity) Party in recent years, particularly since its capture of the greater municipalities of Istanbul and Ankara in the local elections of 1994. Following the collapse of the Motherland Party-True Path Party coalition government formed in the wake of the December 1995 national elections, Refah became the senior party in a new coalition government and its leader, Necmattin Erbakan, the first Islamist Prime Minister in Turkey's history. In the only secular state in the Middle Eastern region, the electoral success of a religious party was a striking achievement. But from the beginning of 1997 , the military set in motion a campaign aimed at driving Refah out of office on the grounds that 'Islamic fundamentalism' was threatening the country's secular character. By the middle of the year, Erbakan had been forced to resign. Most controversially, the party was subsequently threatened with closure by the Constitutional Court. It would not be the first time in Turkey's modern history that a political party has been closed on the orders of the Constitutional Court but it would be the first time a major political party has been shut down.

These developments are watched closely in Europe; but apprehensions about the rise of 'fundamentalism' on the southeastern edge of Europe have to be balanced against more sober realities. Unlike Muslim movements in other countries, Refah has never called for an Islamic system of government in Turkey. It would probably be more accurate to call it a Muslim rather than an Islamic party. Its success can most likely be explained with reference to the unalleviated economic hardships the overwhelming majority of Turks have been suffering for the past 15 years. Refah appeared as an alternative to secular parties of the centre-left and centre-right which were fast losing their credibility because of their failure to match impressive infrastructural growth with greater social justice. Yet it must be remembered that Refah came into government with only $21 \%$ of the vote, and, given the attachment of most Turks to secularism, an Algerian or an Iranian scenario was never likely to unfold in Turkey. The leadership of the Refah is more bourgeois than radical, and during its short time in office the party built on foundations that had already been laid with the consent of the military. It has escaped noone's notice that in the early 1980s military figures themselves encouraged a reassertion of Muslim moral values. Refah's success at the local level has been acknowledged even by its critics, and close analysis of the political situation suggests that secularism only symbolises the struggle for power taking place between the old political class - combining the military, political parties of the centre-left and centre-right, important sectors of the bureaucracy, 


\section{Europe: Rethinking the Boundaries}

media proprietors and the secular intelligensia - and a different if not exactly new social movement adhering to different values, political, economic and cultural in nature, loosely connected by religion and representing the views of a significant percentage of the Turkish population.

What effect was a Refah government likely to have on Turkey's relationships with Europe? The drive towards affiliation with 'western civilisation' began in the nineteenth century and remains perhaps the most important basic marker in Turkey's development. Since 1945, the system of government and foreign relations have been oriented towards the aim of being accepted as a full partner by 'the West'. Integration into Europe has been a priority issue since the 1960s. Turkey was a founding member of the United Nations, is a member of NATO and the Council of Europe, and has been pursuing membership of the European Union (EU) since the Ankara Agreement of Association was signed in 1963. Turkey applied for full membership in 1987, and in 1991 it joined the European Free Trade Association (EFTA). Since then, Turkish governments have initialled a variety of protocols and agreements binding Turkey more closely to the EU. The customs union is the latest of such agreements; yet the goal of actual membership seems more elusive than ever, with other countries moving to the head of the queue since the break-up of the USSR.

There is a certain despair about this, a feeling that Europe is a Christian club which does not want Muslim members (a feeling fortified by the European abandonment of the Bosnians to their fate) and which tends to treat European complaints about the human rights situation in Turkey as a convenient pretext for keeping the door closed. This feeling of rejection has stimulated the Islamic trend. But for all of its inflammatory campaign rhetoric against the EU, the United States and Zionism, once in office the Refah-led government took pains to soothe American and European fears. Certainly Erbakan stressed that he intended to develop relations with the Islamic bloc; but he also confirmed that he would maintain and develop existing relations with Europe and the US, stressed the importance of privatisation and a free market economy, and handed the economic planning portfolio to his junior coalition partner, the True Path Party. 'What we want above all in Turkey is stability ... that is the one thing we have not had and may now have', one of his senior officials was quoted as saying. ${ }^{8}$ If Erbakan entered into commercial dealings with Iran, outraging the United States government, so did European governments-and if these governments are concerned at developments in Turkey now, it is not so much because of the alleged dangers of 'fundamentalism' as because of human rights problems, the role of the military in Turkish politics, and Turkey's chronic economic problems. The Prime Minister appointed to succeed Necmettin Erbakan, Mesut Yilmaz, leader of the Motherland Party, has admitted that the state of the economy alone is a serious barrier to European integration, 
and that it is 'not possible' to achieve social harmony in a country where the annual inflation rate for more than a decade has hovered in the range of 100 per cent. The Turkish lira, running at 14,000 to the US dollar towards the end of 1993, had depreciated by November 1997 to more than 185,000 against the dollar. Successive governments have come into office promising to bring inflation down, but none has succeeded, and the official goal of bringing Turkey's inflation rate within the ambit of the average rate in EU countriesabout two per cent-is clearly a pipedream for the foreseeable future. Fresh intervention by the military in 1997-a 'soft coup' similar to the 'coup by memorandum' in 1971 when the army forced the resignation of the government and the appointment of a new Prime Minister-has done further damage to Turkey's image in Europe by demonstrating yet again that the court of last resort in Turkish politics is not the ballot box but the Turkish General Staff. This pushes Turkey further away from EU membership. Ian O. Lesser, a senior analyst with the Rand Corporation, observes in a recent paper that

Europe is likely to hold Turkey at arm's length through 2010 and beyond. Closer economic relations, including the full implementation of the customs union, are possible but full membership in the EU and the West European Union (WEU) will almost certainly be unattainable. Europe will continue to view Turkey as a useful barrier to instability in the south and east rather than a cultural, political and economic bridge. Cultural unease, economic and migration concerns, human rights complaints and worries about the security 'baggage' Turkish EU membership would imply all suggest that Turkey will remain in institutional limbo on Europe's periphery.

But Turkey is only one of many countries around the southern and eastern rim of the Mediterranean that present a similar range of problems. According to Lesser 'there can be little doubt that the areas on the southern periphery, from the Maghreb to Turkey's Middle Eastern borders, will be the scene of crisis and change over the next decades'. The causes of incipient or actual turmoil include economic instability, ethnicity, regime oppression and national rivalries. Hostility between Greece and Turkey over a range of issues has threatened to precipitate a conflict with serious regional and international ramifications on several occasions, posing a far greater danger to European security than internally-directed Muslim revivalism. ${ }^{9}$

What does the rise of Islamic movements spell for Europe? The point has been made that their priority is internal change and reform. There are absolutely no grounds for assuming intrinsic hostility to 'the West', its people or its governments. There are real problems, but in no sense are they the outcome of a 'clash' of civilisations. They are largely the outcome of differences over territory and resources. Islamic movements and governments are little different 


\section{0}

from the nationalist movements of four decades ago in their determination to resist external control. But whatever the flavour of governments that come to power in Muslim societies, they will need to buy and sell and deal with the outside world. In this respect, the changes made to economic policy by the Iranian government, directed towards attracting foreign investment in Iran, are very striking.

Changes in these societies obviously have spillover effects for Europe. In addition to state-to-state relations-or relations between the European Union and these states - the changes now taking place across the Muslim world expose the sizeable Muslim communities in Europe to added scrutiny. Every single incident, whether it be a terrorist bombing or the wearing of a veil to school, highlights their 'otherness' and raises not just questions of cultural difference but of ultimate loyalties. Problems of acculturation and adaptation are always difficult to resolve, and to a degree Muslims bring their problems with them - as immigrants do everywhere - but not only as Muslims. Kurds have attacked each other in Europe, and the Kurdistan Workers' Party (PKK) has carried its campaign against the Turkish government to European cities. Iranian exiles have been murdered in Paris, and France will continue to be a surrogate arena for the conflict being waged in Algeria. But what percentage of the millions of Muslims living in Europe will ever be involved in any of these activities? Their 'otherness' certainly exposes them to a degree of collective blame applied to no other group. As the director of the Institute of Race Relations in London has written, immigration has given rise to a 'Euro-culture of popular racism which stereotypes all Third World/Black immigrants as terrorists and drug-runners and all East European/White immigrants as thieves and shoplifters'.${ }^{10}$ These views are reinforced by pseudo-academic stereotypes which present Muslims as the 'gravediggers of the Christian civilisations they conquered', Bosnia-Herzegovina as 'the spearhead of a future Islamic thrust into Europe' and Europe itself as the object of a process of Islamisation. ${ }^{11}$ The ability to make such statements about Bosnia at a time the Bosnian Muslims were being massacred says a great deal about the depth of the anti-Islamic sentiment that still exists in Europe. These appalling ideas, these misrepresentations of history and Islam, give credibility to the idea that there is a 'clash' of civilisations between Europe and Islam. Differences there certainly are, as there are between all civilisations and cultures; but the real problems that arise between the external world and Muslim societies are rooted-as has been noted-not in religion but in the control of territory and resources. As Chandra Muzaffer has written,

...resistance to western domination and control-and not some threat to the West as such-which is taking place in the Muslim world is a reality that is cleverly concealed from the general public. ${ }^{12}$ 
We see this very clearly in the Middle East where 'western interests' are still focused on the need to keep the Gulf in safe hands and to punish or pacify troublemakers. The Middle East is now 'safer' for 'the West' than at any time since 1945. Radical nationalism has come and gone and so has communism. Iraq is prostrate, and the PLO is negotiating with Israel. Egypt is so heavily in debt that true independence is a luxury it can no longer afford: its present state of indebtedness bears comparison to the Egypt of the khedives more than a century ago. Saudi Arabia continues to buy masses of arms from Britain and the United States which it will never use and whose only purpose can be to bind western states more closely to the survival of the Saudi regime. Serving the interests of the West in one way or another, all of these regimes are under threat from within, on the grounds of their corruption, their incompetence and their unrepresentative nature, and they are opposed not just by the 'fundamentalists' but by thoroughly secularised Muslims. Yet it is their stability that the West means when it talks of 'regional stability', in defence of which Western policymakers attack 'fundamentalism' and its principal standard bearers with such venom. It is in this context that we should understand the targeting of Iran in particular.

Increasingly, as we move into the twenty-first century, it seems that 'fundamentalism' is the ideological hammer that might eventually break the mould in which the present Middle Eastern state system has been cast. This will have ramifications for Europe but-to reiterate-Muslim movements are working first to change their own systems, and only secondarily to establish a more independent way of dealing with the West. But this, it seems, is precisely what 'the West' and principally the United States does not want.

What some Europeans seem to be resisting is the acknowledgement that Islam is now a fact of European life. The tide of immigration can be slowed down and even dried up, but unless Muslim communities are to be deprived of basic political and civil rights, European governments have no option but to integrate them into the fabric of their societies. This means making allowances for cultural difference in all sorts of ways. There will be problems of adaptation on both sides, and no doubt the racists will continue to use every opportunity to inflame public opinion against Muslim (and other) communities. However, there are now millions of Muslims who are native-born Europeans, and as time passes the similarities between them and other Europeans are likely to become greater than are the differences. ${ }^{13}$ Nevertheless, for those on the receiving end, European racism and nationalist xenophobia is an embittering and sometimes fatal experience. North African, Middle Eastern and African immigrants are already at the bottom of the socio-economic ladder, and attempts to delegitimise their culture and present them as a people apart can only widen the gaps which the European governments say they are trying to close, and force them to fall back on their native identity. The failure of governments 


\section{Europe: Rethinking the Boundaries}

to deliver services is already driving them in this direction: in the urban housing projects where the Muslim migrant communities are concentrated and where 'crime, drugs and physical decay' have taken over, Islam

has stepped in as a stabilising force ... fundamentalist groups have created socioreligious associations, teaching the Koran, Arabic and martial arts, offering summer camps for kids and providing aid to the poor. ${ }^{14}$

In short, cultural differences should be acknowledged only for what they are, and not as a sign that 'Islam' and 'western civilisation' are mutually antipathetic. There are cultural differences arising from the differences between Islam and other religions; there are differences between Muslim and nonMuslim states, as there are between any states; and for Muslims living in Europe there are the difficulties of acculturation and acceptance. But to subsume these problems in a 'clash of civilisations' in the irreducible sense implied by those who use the phrase would seem to seriously and dangerously misrepresent the issues involved.

\section{Notes}

1. S. Huntington, 'The Clash of Civilisations?', Foreign Affairs, 72 (3), 1993, 22-49. See also L. Holmes' chapter in this volume.

2. As reported by The Age, 4 February 1995,8 .

3. M. Sheridan, 'France haunted by spectre of past war', written for The Independent and reprinted in The Age, 29 December 1994, 13.

4. J. Ruedy, 'Continuities and Discontinuities in the Algerian Confrontation with Europe', in J. Ruedy, (ed.), Islamism and Secularism in North Africa, Centre for Contemporary Arab Studies (Georgetown University, 1994), 75.

5. L. Sadiki, 'The Roots of Algeria's Maelstrom', Middle East Quarterly, 2 (6), (1994), 22.

6. Ibid., 23.

7. Sheridan, loc. cit., 13.

8. Quoted in New Europe, 7-13 July 1996, 33.

9. 'Scenarios unclear on future picture of Turkey and Eastern Mediterranean countries,' Turkish Daily News, 11 November 1997, 8.

10. A. Sivandan, writing in E. Fekete and F. Webber (eds), Inside Racist Europe (Institute of Race Relations, 1994), v.

11. Bat Ye'or, 'The Return of Islam to Europe', Mainstream, February/March 1994, 16-19.

12. C. Muzaffer, 'The Clash of Cultures or Camouflaging Domination', Asian Studies Review, 18 (1), 1994, 9.

13. As J. S. Nielsen observes, there has been a continuous Muslim presence in Europe 'virtually since the beginning of Muslim history'. The activities of the overt racists aside, 'in the last analysis the question must be how far European society itself is prepared to adapt. It is an adaptation that is extremely difficult to contemplate, as European cultures seem to have entrenched themselves to a degree unusual in history. Monocultural and monolingual 
nation states, often legitimating one religion and one legal system, grew up in the eighteenth and nineteenth centuries. Their identity, self confidence, often very raison d'être, was founded on superiority over others internally and externally.' Nielsen, 'Muslims in Europe in the Late Twentieth Century' in Y. Yazbeck Haddad and W. Z Haddad (eds), ChristianMuslim Encounters (University Press of Florida, 1995), 323-4.

14. S. Waxman, 'France and the veil', written for the Washington Post and reprinted in The Age, 11 January 1995, 16. 